\title{
EVALUATION OF AN L-SHAPED EXTRUSION \\ OF P/M ALLOY 718
}

\author{
Edward A. Loria \\ Metallurgical Consultant* \\ 1828 Taper Drive \\ Pittsburgh, Pennsylvania 15241
}

\begin{abstract}
A unique advantage of $\mathrm{P} / \mathrm{M}$ processing is in producing near-net shape or even final shape products. This survey of a channel extrusion produced directly from a consolidated billet of $\mathrm{P} / \mathrm{M} 718$ reveals that excellent mechanical properties and uniform grain size are obtained. Tensile properties at ambient and at $650^{\circ} \mathrm{C}$ and stress rupture at $650^{\circ} \mathrm{C}$ exceed the internal specification for a rolled profile as well as the AMS specifications for cast and wrought 718 . From a property and cost standpoint, the P/M near-net shape is superior to the rolled profile from conventional cast-wrought operations. Also, properties are compared with other special products of $\mathrm{P} / \mathrm{M} 718$ that were studied previously, and an SEM analysis of a stringer aggregate in the $\mathrm{P} / \mathrm{M} 718$ extrusion is provided.
\end{abstract}

\footnotetext{
* At the time of this investigation, Supervisory Research Metallurgist, Universal-Cyclops
} Specialty Steel division (now Cytemp Powder Products Division), Bridgeville, PA.

Superalloys 718, 625 and Various Derivatives

Edited by Edward A. Loria

The Minerals, Metals \& Materials Society, 1991 


\section{Introduction}

The advantages cited for the use of powder metallurgy include the ability to make complex alloys not possible with conventional techniques, freedom from segregation, finer grain size, superplastic forming and hot consolidation processes to produce near-net shapes. Developed initially for advanced materials that could only be made this way, the technology can be applied equally well to high volume superalloys. The structure and properties of $\mathrm{P} / \mathrm{M}$ Alloy 718 have been shown to be at least comparable and in some instances superior to the conventionally produced wrought counterpart. ${ }^{1}$ Although the replacement has been slow because of the extensive experience built up for the latter, the $\mathrm{P} / \mathrm{M}$ approach is being explored for specific products. Heavy wall tubing has been produced from P/M 718 tube hollows via successive cold reductions on a Pilger mill and lighter wall tubing has been produced by radial cold forging of $\mathrm{P} / \mathrm{M} 718$ tube hollows in a Grotnes machine. ${ }^{2}$ Even cross rolled plate has been examined from solid P/M 718 billet. Also, P/M 625 billet has been extruded and then hot and cold rolled to coil product for redraw-stock welding wire ${ }^{3}$ In all cases, the powders were consolidated by atmospheric pressure in glass molds, the CAP process. ${ }^{1}$ To add to these exploratory studies, this paper provides results obtained on an L-shaped channel produced by extrusion of P/M 718 which could be a replacement of a rolled profile that is fabricated into an aircraft turbine component.
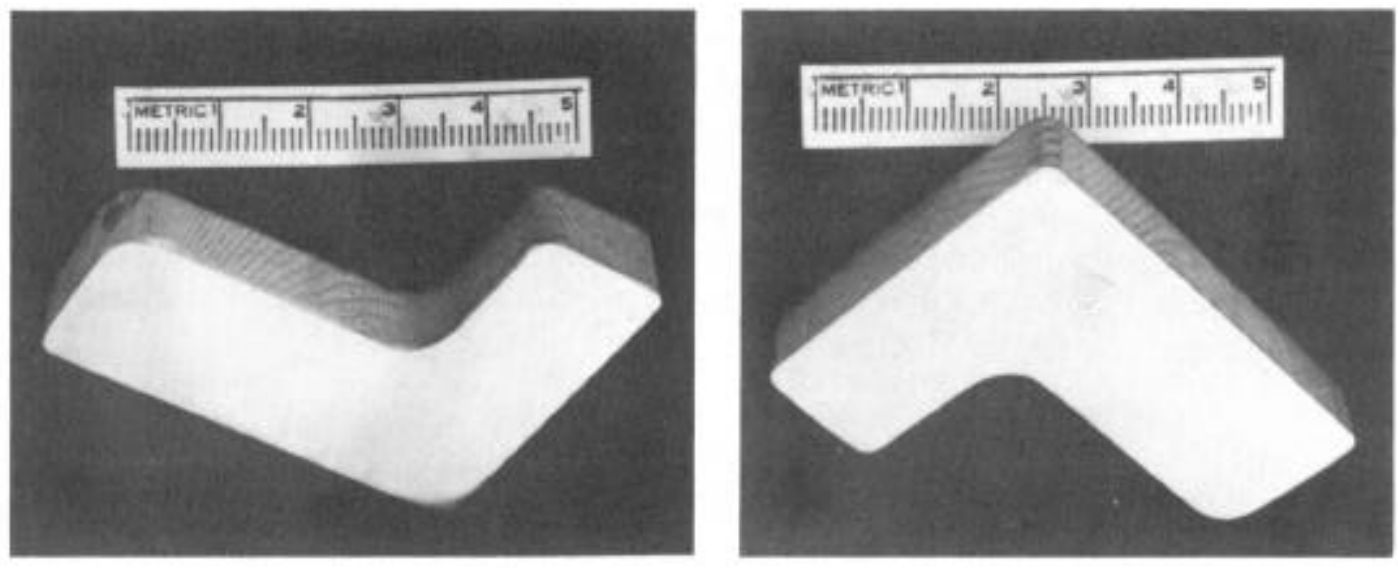

Figure 1. End views and flow line contours produced during extrusion of $\mathrm{P} / \mathrm{M} 718$ billet into an L-shaped channel.

\section{Experimental Procedure}

The extruded shape was produced from a $5 \mathrm{in}$. round by $30 \mathrm{in.}$ long P/M CAP718 billet derived from a heat whose principal composition was $53.2 \mathrm{Ni}, 18.3 \mathrm{Cr}$, $18.6 \mathrm{Fe}, 5.4 \mathrm{Nb}, 3.0 \mathrm{Mo}, 0.94 \mathrm{Ti}$ and $0.55 \mathrm{Al}$ in wt.pct. The remaining residual elements were $0.10 \mathrm{Mn}, 0.11 \mathrm{Si}, 0.005 \mathrm{P}, 0.002 \mathrm{~S}$ and $0.058 \mathrm{C}$. The L-shaped channel was extruded at $1100^{\circ} \mathrm{C}$ by a proprietary process employing optimum extrusion flow stress for $\mathrm{P} / \mathrm{M} 718$ derived from the billet section, the optimum extrusion ratio and the alloy's high temperature flow stress. The dimensions of the extruded profile were $21 / 8$ in. height with $13 / 16$ in. thickness and $13 / 4$ in. base with $5 / 8$ in. thickness, 
per Figure 1. The macrostructure appeared uniform both visually and under binoculars. Metal flow lines in various parts of the extrusion are seen in Figure 1 and the clean contours are important aspects of the successful processing of this very stiff alloy. Longitudinal specimens were cut from the base and vertical of the extruded channel and subjected to metallography, tensile and stress rupture testing after the specified heat treatments.

\section{Results}

The grain size of the extruded channel was uniform ASTM7 as seen in the longitudinal views of Figure 2. The presence of stringers, dispersed throughout the microstructure, would not be of any concern to mechanical properties which
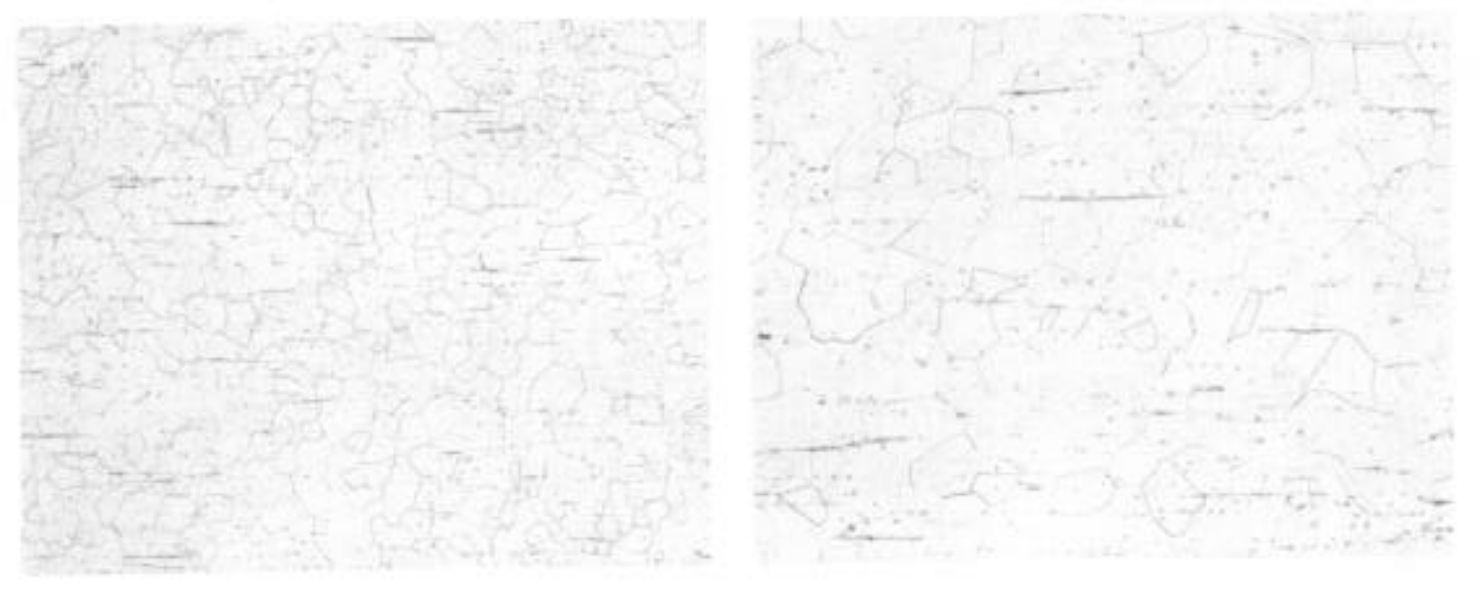

Figure 2. Microstructure in longitudinal direction of $P / M$ A1loy 718 extruded shape. (a) X100. (b) X200.

would only be requisite in the longitudinal direction for the component fabricated from the channel. Room temperature tensile test results for the two specific heat treatments listed in Table I exceed the specification for rolled profiles from castwrought practice. The $995^{\circ} \mathrm{C}$ or $990^{\circ} \mathrm{C}$ solution treatments provided higher values than as extruded or as extruded plus direct aged product. It is somewhat surprising that the latter did not maximize tensile strength which is the usual case. Also, the values obtained for the two solution treatments exceed the specified $185 \mathrm{ksi}$ ultimate, $150 \mathrm{ksi}$ yield, 12 pct elongation and 15 pct reduction of area in AMS5662B and 5663B for bars, forgings and rings and AMS5589 for seamless tubing produced by conventional $\mathrm{CW}$ processing.

The tensile test results at $650^{\circ} \mathrm{C}$, per Table II, reveal that either heat treatment on the extruded channel provided values that exceed the internal specification established for a rolled profile. Again, the results are well above the requirements of the above AMS specs for other CW products which are $145 \mathrm{ksi}$ ultimate, $125 \mathrm{ksi}$ yield with 12 pct elongation and 15 pct reduction of area. Finally, the stress rupture results at $650^{\circ} \mathrm{C}$ under a stress of $100 \mathrm{ksi}$, listed in Table III, exceed the requirements of the internal specification as well as the above AMS spec requirements of 23 hours and 4 pct elongation for a stress of $100 \mathrm{ksi}$ at $650^{\circ} \mathrm{C}$. 


\section{Table I Tensile Test Results at $20^{\circ} \mathrm{C}$ on P/M CAP 718 Extruded Shape}

\begin{tabular}{|c|c|c|c|c|c|c|}
\hline Metallurgical State & \multicolumn{2}{|c|}{$\begin{array}{c}\text { Ultimate } \\
\text { Stress } \\
\end{array}$} & \multicolumn{2}{|c|}{$\begin{array}{c}0.2 \% \text { Yield } \\
\text { Stress } \\
\end{array}$} & $\begin{array}{c}\text { Elong. } \\
\%\end{array}$ & $\begin{array}{l}\text { Red. of } \\
\text { Area, \% }\end{array}$ \\
\hline $\begin{array}{l}\text { Required values in Spec DND } 424 \text { and } \\
\text { DNF } 90420-01 \text { on products }\end{array}$ & $\geqslant 180$ & $\geqslant 1240$ & $\geqslant 149$ & $\geqslant 1030$ & 12 & 15 \\
\hline $\begin{array}{l}\text { As-extruded L-shape, } \\
\text { Profile } 2466 \mathrm{~A}\end{array}$ & $\begin{array}{l}130 \\
132\end{array}$ & $\begin{array}{l}898 \\
909\end{array}$ & $\begin{array}{l}66 \\
67\end{array}$ & $\begin{array}{l}454 \\
463\end{array}$ & $\begin{array}{l}53 \\
51\end{array}$ & $\begin{array}{l}48 \\
43\end{array}$ \\
\hline $\begin{array}{l}\text { Extruded and heat treated } \\
\text { at } 995^{\circ} \mathrm{C} / 1 \mathrm{hr} \text {, air + aging }\end{array}$ & $\begin{array}{l}197 \\
199\end{array}$ & $\begin{array}{l}1359 \\
1372\end{array}$ & $\begin{array}{l}174 \\
169\end{array}$ & $\begin{array}{l}1199 \\
1164\end{array}$ & $\begin{array}{l}22 \\
19\end{array}$ & $\begin{array}{l}34 \\
31\end{array}$ \\
\hline $\begin{array}{l}\text { Extruded and heat treated } \\
\text { at } 990^{\circ} \mathrm{C} / 2 \mathrm{hr} \text {, air + aging }\end{array}$ & 196 & 1357 & 173 & 1190 & 22 & 34 \\
\hline As extruded + direct aging & 195 & 1343 & 167 & 1152 & 22 & 35 \\
\hline
\end{tabular}

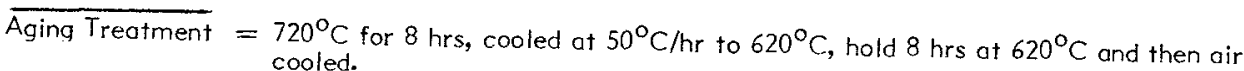

Table II Tensile Test Results at $650^{\circ} \mathrm{C}$ on P/M CAP 718 Extruded Shape

\begin{tabular}{|c|c|c|c|c|c|c|}
\hline Metallurgical State & \multicolumn{2}{|c|}{$\begin{array}{l}\text { Ultimate } \\
\text { Stress } \\
\end{array}$} & \multicolumn{2}{|c|}{$\begin{array}{l}0.2 \% \text { Yield } \\
\text { Stress }\end{array}$} & $\underset{\%}{\text { Elong. }}$ & $\begin{array}{l}\text { Red. of } \\
\text { Areo, \% }\end{array}$ \\
\hline $\begin{array}{l}\text { Required values in Spec DND 424-22 } \\
\text { and DNF90420-01 }\end{array}$ & $\geqslant 1 / 15$ & $\geqslant 1000$ & $\geqslant 125$ & $\gg 860$ & 10 & 15 \\
\hline $\begin{array}{l}\text { Extruded and heat treated at } \\
955^{\circ} \mathrm{C} / 1 \mathrm{hr} \text {, air }+ \text { aging }\end{array}$ & 153 & 1055 & 138 & 952 & 11 & 16 \\
\hline $\begin{array}{l}\text { Extruded and heat treated at } \\
990^{\circ} \mathrm{C} / 2 \mathrm{hrs} \text {, air + aging }\end{array}$ & 158 & 1088 & 143 & 987 & 10 & 19.5 \\
\hline
\end{tabular}

Aging Treatment $=720^{\circ} \mathrm{C}$ for $8 \mathrm{hrs}$, cooled at $50^{\circ} \mathrm{C} / \mathrm{hr}$ to $620^{\circ} \mathrm{C}$, hold $8 \mathrm{hrs}$ of $620^{\circ} \mathrm{C}$ and then air cooled.

Table III Stress Rupture Results at $650^{\circ} \mathrm{C}$ in P/M CAP 718 Extruded Shape

\begin{tabular}{|c|c|c|c|c|c|}
\hline \multirow[b]{2}{*}{ Metallurgical State } & \multicolumn{3}{|c|}{ Test Conditions } & \multirow[b]{2}{*}{$\begin{array}{l}\text { Time } \\
\text { Hrs. }\end{array}$} & \multirow[b]{2}{*}{$\begin{array}{c}\text { Elong. } \\
\quad \% \\
\end{array}$} \\
\hline & Temp. ${ }^{\circ} \mathrm{C}$ & $\widehat{\mathrm{ksi}}$ & $\frac{\mathrm{ss}}{\mathrm{MPa}}$ & & \\
\hline $\begin{array}{l}\text { Required volues in Spec. DND } \\
424.22 \text { and DNF90420-01 }\end{array}$ & 650 & 100 & 690 & 23 & 5 \\
\hline $\begin{array}{l}\text { Extruded and heat treated at } \\
955^{\circ} \mathrm{C} / \mathrm{hr} \text {, air + aging }\end{array}$ & 650 & 100 & 620 & 103 & 7.7 \\
\hline $\begin{array}{l}\text { Extruded and heat treated of } \\
990^{\circ} \mathrm{C} / 1 \mathrm{hr} \text {, air }+ \text { aging }\end{array}$ & 650 & 100 & 690 & 83 & 11.2 \\
\hline
\end{tabular}




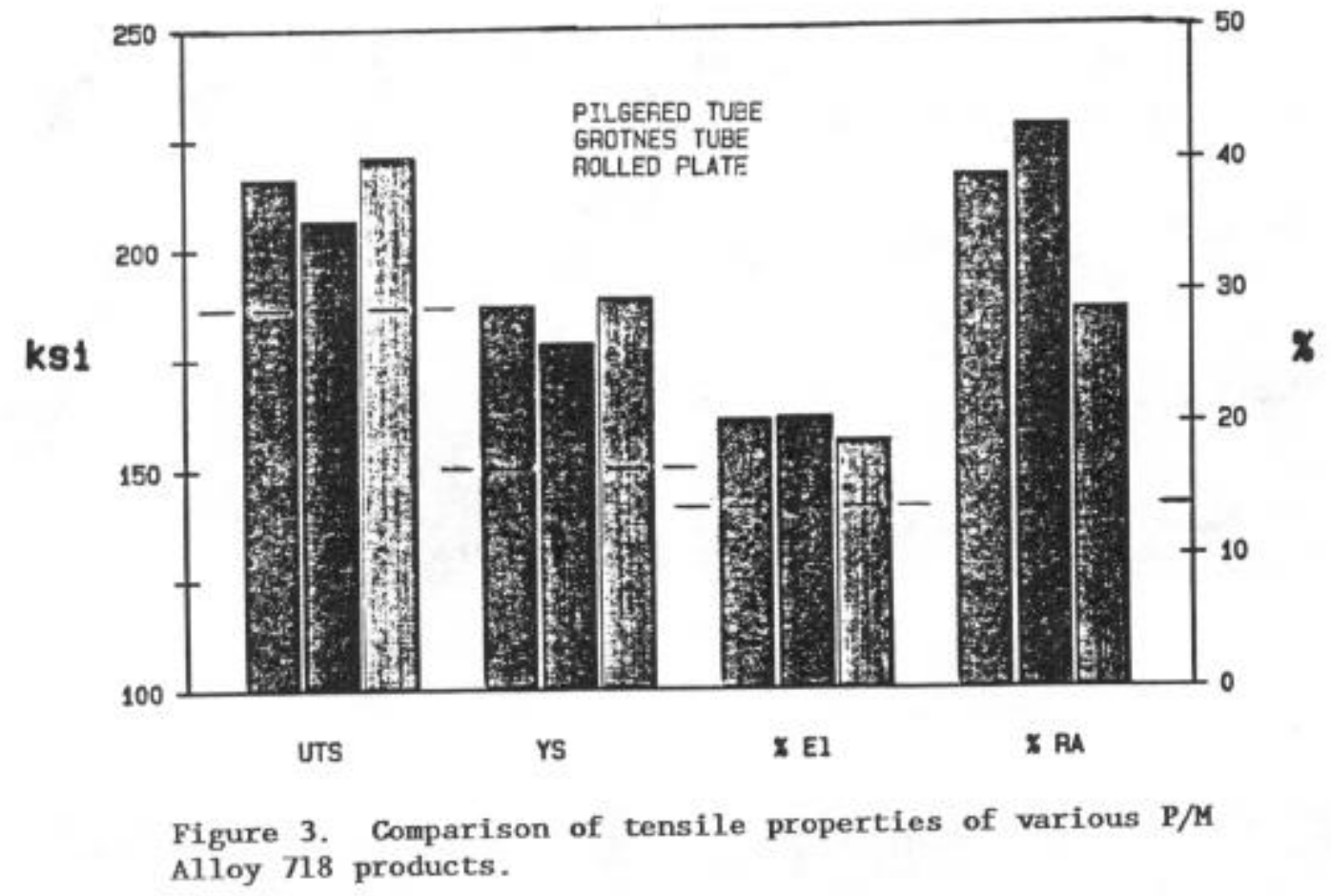

Figure 3 is presented as a summary of the tensile test results obtained on the earlier end-products derived from $\mathrm{P} / \mathrm{M}$ 718. Although there are finite differences between them which can be explained on the basis of the different mechanical working procedures and heat treatments, the properties for all three products greatly exceed the specification requirements for cast and wrought 718 . Adding the present results on the L-shaped extrusion of $\mathrm{P} / \mathrm{M} 718$ to our prior work, it is evident that somewhat lower values for ultimate and yield strength were obtained but still significantly higher than the $\mathrm{CW}$ spec requirement. Again, a strict
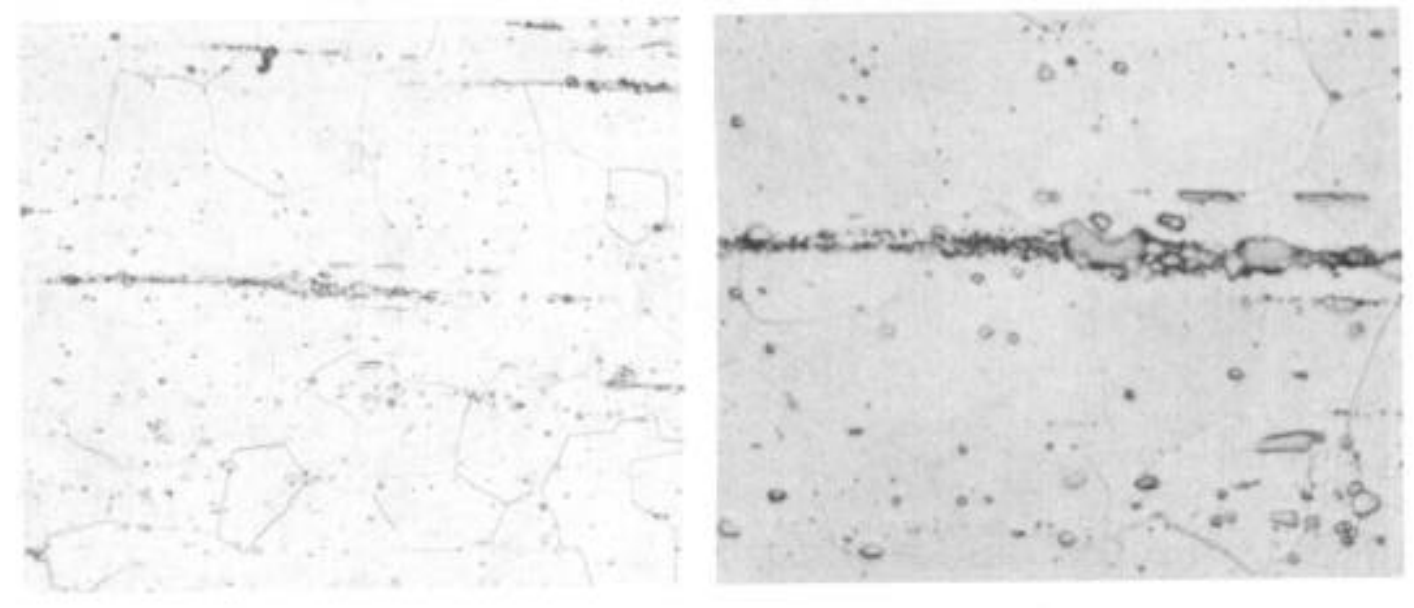

Figure 4. Optical photomicrographs of stringers in extruded shape of $\mathrm{P} / \mathrm{M}$ Alloy 718 . (a) $\mathrm{X} / 400$. (b) $\mathrm{X} 1000$. 

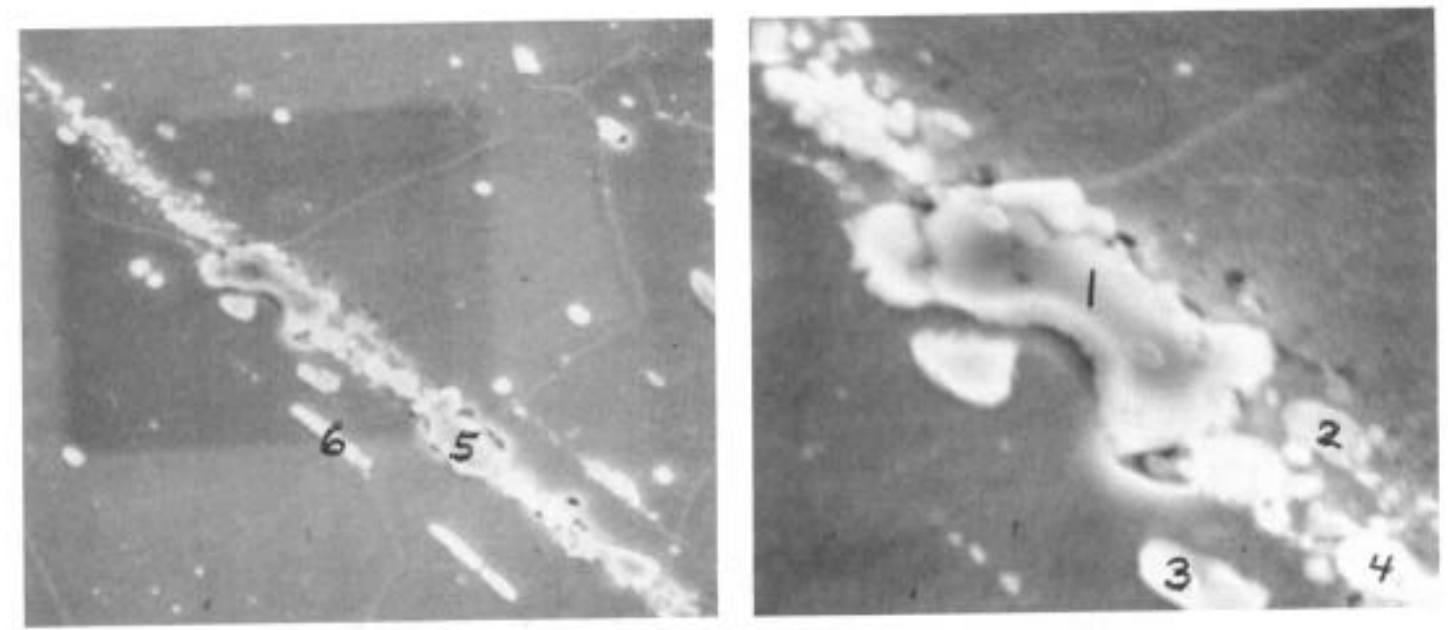

Figure 5. Secondary electron images of stringer aggregate in extruded shape of $\mathrm{P} / \mathrm{M}$ Alloy 718. (a) X1000. (b) $\times 3000$. Numbered particles subjected to EDAX.
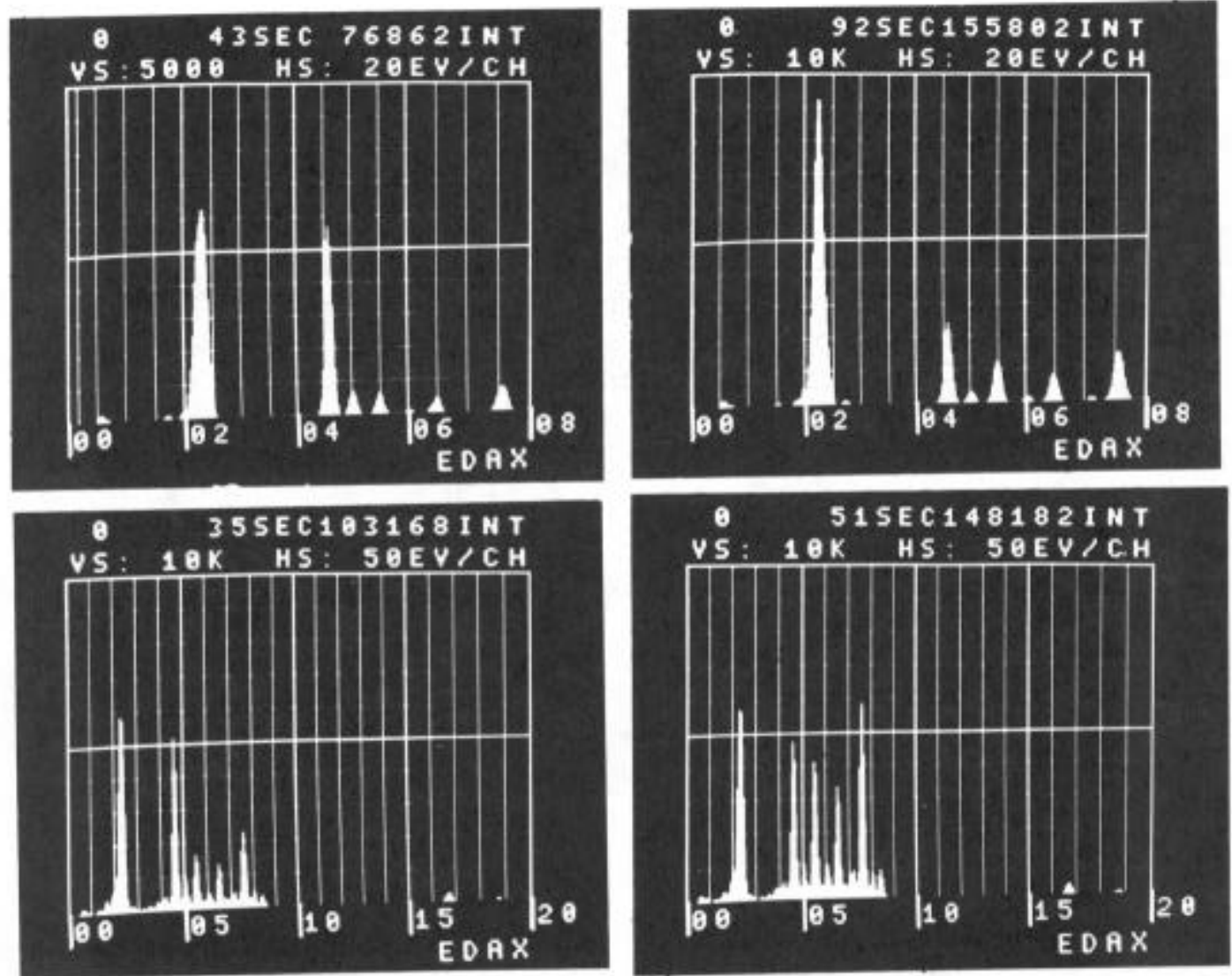

Figure 6. EDAX of numbered particles in Figure 5. (a) Particle 1, with particles 5 and 6 identical to this EDAX. (b) Particle 2, with particles 3 and 4 identical to this EDAX. (c) Particle 1 in the range to detect the presence of secondary peaks for $\mathrm{Nb}$ and $\mathrm{Mo}$. (d) Particle 6 in the range to detect the presence of secondary peaks for Nb and Mo. 
comparison between this product and the earlier ones is really not justified for the above reasons. However, it can be noted that the ultimate tensile strength of Standard Process 718 is $185 \mathrm{ksi}$ for ASTM4-6 grain size. Also, it has been reported that the P/M 718 extruded channel has better properties than those obtained on the rolled profile, and there would be a cost advantage for this near-net shape compared to the extensive rolling operations when starting with $\mathrm{CW}$ material.

While it is not possible to make perfect material, the industry has made great strides in powder production in order to provide a cleaner, more structural uniform material. In this regard, an inclusion stringer distributed in the extrusion direction was examined via the scanning electron microscope. Optical photomicrographs are shown in Figure 4 and the secondary electron images of the aggregate via the SEM are seen in Figure 5, with the individual particles that were specifically analyzed enumerated as 1 to 6 .

The energy dispersive $\mathrm{x}$-ray analysis (EDAX) of large particle 1, per Figure 6a, revealed a strong $\mathrm{Nb}-\mathrm{Mo}$ peak and a nearly equivalent Ti peak at the expected positions and the analyses made on smaller particles 5 and 6 were identical to particle 1 . The analysis of small particle 2, shown in Figure $6 \mathrm{~b}$, revealed a strong $\mathrm{Nb}-\mathrm{Mo}$ pack and a smaller Ti peak, in a ratio of 3 to 1 , and the analyses of particles 3 and 4 were identical to particle 2 . With this ratio, past experience indicates these particles can be identified as carbide. With the nearly equal $x$-ray counts (peak heights) for $\mathrm{Ti}$ and the $\mathrm{Nb}-\mathrm{Mo}$, the large angular particle 1 and the smaller, separate rod-shaped particle 6 appear similar to known sulfides in high temperature alloys and could possibly be titanium carbosulfides. However, when the EDAX scale was expanded to distinguish secondary peaks which were seen, per Figure $6 \mathrm{c}$ and $6 \mathrm{~d}$, this possibility was discarded since sulfur has no secondary peaks.

It is known that primary carbides in Alloy 718 are Nb-rich carbides. Hence, an EDAX was made on a primary carbide located away from the stringer aggregate, per Figure 7a. As seen in the expanded scale, Figure 7b, the carbide particles exhibit the
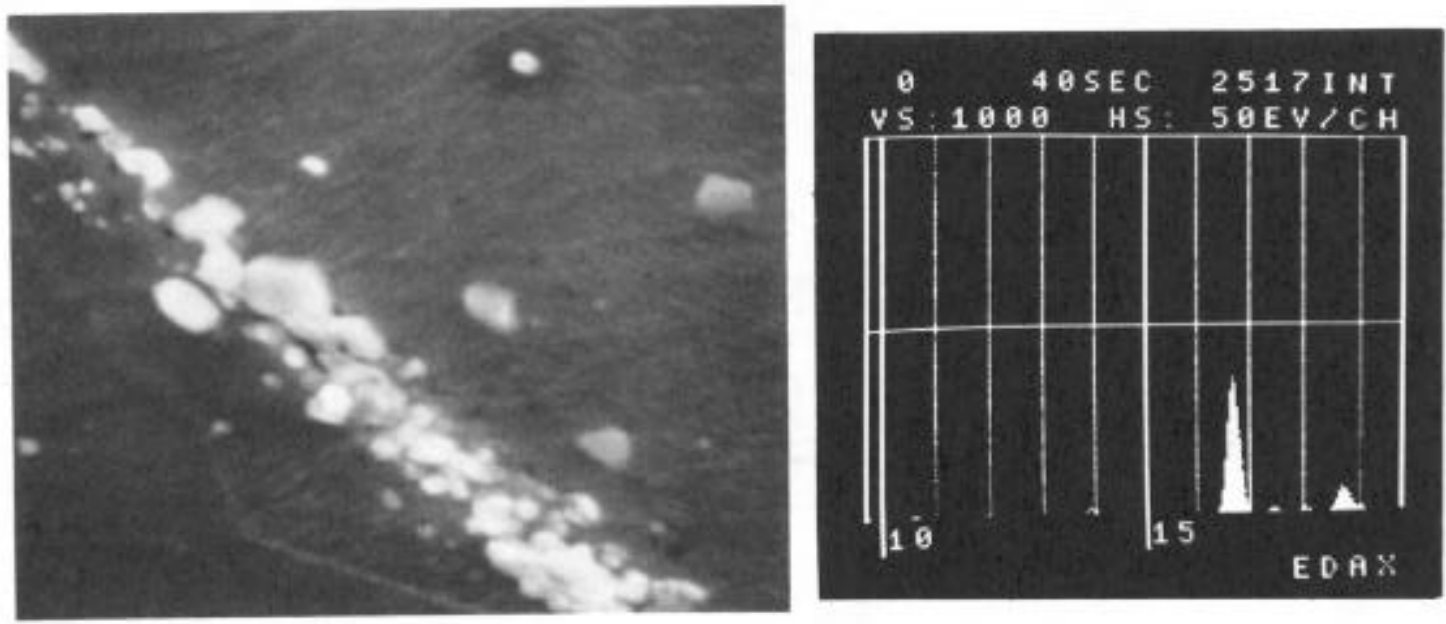

Figure 7. Secondary electron image of area showing typical primary carbides located away from stringer segregate at $\mathbf{X} 3000$ and EDAX of carbide particle to show similarity between its $\mathrm{Nb}$ and Mo secondary peaks with those obtained on rod-shaped Particle 6 which appears as tiny dots on top of the peaks obtained from the primary carbide particle. 
characteristic secondary $\mathrm{Nb}$ peaks. Recalled from the memory were the secondary $\mathrm{Nb}$ peaks for the rod shaped particle 6 which superimposed directly on this scale. Since the two sets of secondary peaks are identical and from spectra with primary $\mathrm{Nb}$-Mo peaks of the same intensity, the only logical conclusion is that the rodshaped particles do not contain sulfur.

It is recognized that the complete composition of the stringer aggregate is still not known and possibly more information on it could be obtained by bulk extraction of the stringers and $\mathrm{x}$-ray diffraction analysis of the extracted residue. However, this would be an analysis of a bulk residue and it would still not be possible to separate and obtain an analysis of the individual particles provided by EDAX via SEM.

\section{References}

1. J.F. Radavich and D.J. Meyers, Superalloys 84, Proc. Fifth International Symposium, ASM (1984), pp. 347-356.

2. E.A. Loria, Superalloy 718: Metallurgy and Applications, TMS (1989), pp. 427-436.

3. E.A. Loria, Paper in this volume. 